\title{
RELATIONSHIP BETWEEN SOCIODEMOGRAPHIC ASPECTS, SATISFACTION AND LOYALTY IN GASTRONOMIC FESTIVALS
}

\author{
Mauricio CARVACHE-FRANCO* \\ Universidad Espíritu Santo-Ecuador, Facultad de Turismo y Hotelería, \\ Km. 2.5 Vía a Samborondón, Samborondón, Ecuador, e-mail, mauricio2714@ hotmail.com \\ Orly CARVACHE-FRANCO \\ Universidad Católica de Santiago de Guayaquil. Facultad de Especialidades Empresariales, \\ Km 1.5 Av. Carlos Julio Arosemena, Guayaquil, Ecuador, e-mail: orly.carvache@cu.ucsg.edu.ec \\ Wilmer CARVACHE-FRANCO* \\ Escuela Superior Politécnica del Litoral, ESPOL. Facultad de Ciencias Sociales y Humanísticas, \\ Campus Gustavo Galindo Km 30.5 Vía Perimetral, P.O. Box 09-01-5863, Guayaquil, Ecuador, e-mail: wcarvach@espol.edu.ec \\ César VILLAGóMEZ-BUELE \\ Universidad de Guayaquil, Facultad de Ingeniería Química, \\ Cdla. Universitaria, Av. Delta y Av. Kennedy, Guayaquil, Ecuador, e-mail: cesar.villagomezb@ug.edu.ec

\begin{abstract}
Citation: Carvache-Franco, M., Carvache-Franco, O., Carvache-Franco, W., \& Villagómez-Buele, C. (2020). RELATIONSHIP BETWEEN SOCIODEMOGRAPHIC ASPECTS, SATISFACTION AND LOYALTY IN GASTRONOMIC FESTIVALS. GeoJournal of Tourism and Geosites, 32(4), 1324-1329. https://doi.org/10.30892/gtg.32420-576
\end{abstract}

\begin{abstract}
Currently, the organization of gastronomic festivals is an opportunity to rescue the culture and development of a destination. The present study was carried out in the city of Naranjal, Ecuador at the "Gastronomic Festival of the Red Crab" and its objectives are: (i) to identify the relationship between the level of education and income, as sociodemographic variables as well as the level of satisfaction of people attending a Gastronomic Festival. (ii) identify the influence of satisfaction on the probability of revisiting a Gastronomic Festival. Two hundred valid questionnaires completed on-site by national and international visitors during the event were used. Pearson's Chi square and Spearman's Correlation were applied for data analysis. The results show that the level of satisfaction of the attendees is influenced by their level of education and income. Furthermore, the probability of revisiting the event is influenced by the level of satisfaction of the attendees. The results will contribute to the academic literature and the information will be used for service providers to develop products according to demand.
\end{abstract}

Key words: Festival, gastronomy, satisfaction, sociodemography, loyalty

$* * * * * *$

\section{INTRODUCTION}

A gastronomic festival is a set of recreational events where regional food is presented (Lee and Arcodia, 2011). Hence, local inhabitants in diverse destinations have created food festivals (Horng et al., 2013). As a celebration of cultures and values, festivals enrich the knowledge that surrounds the participants (Goldblatt, 2011). Food festivals can represent cultural values and regional identities (Meneguel et al., 2019). Hence, events are an important motivating element of tourism and one of the keys in the development of many tourist destinations (Getz, 2008). In this sense, destination marketing organizations should pay attention to the link between the destination image and food events (Privitera et al., 2018). In this framework, Ecuadorian gastronomy has its origins with the arrival of the Spanish, who later created typical dishes in the different regions: coast, highlands, amazon region and insular region. The Gastronomic Festival of the Red Crab is celebrated annually in August in Naranjal, Ecuador. Since 2014, this gastronomic event is held on the first Sunday of August each year. The festival is an event where national and foreign tourists attend to taste a variety of dishes made from the Red Crab and, visitors also recreate with artistic and cultural activities. Within this context, studies on the demand for gastronomic festivals are scarce, and no concrete cases have been found that analyze the relationship among satisfaction sociodemographic variables and the probability of visiting a gastronomic festival. Therefore, the present study focused on studying the Gastronomic Festival of the Red Crab in Ecuador and generalizing the results. Hence, the objectives were: (i) to identify the relationship between the le vel of education and income, as sociodemographic variables, and the level of satisfaction of attendees in a gastronomic festival and (ii) identify the influence of satisfaction on the probability of returning to a gastronomic festival. The results contribute to the academic literature on gastronomic festivals and as information for service providers and destination administrators to improve the satisfaction of the event.

\section{LITERATURE REVIEW}

Festivals or events present fundamental advantages for destinations based on economic growth opportunities by providing new life to existing companies, developing new businesses and generating revenue for governments (Dwyer et al., 2005; Huang et al., 2010). In this regard, the importance of wine and food in the tourist experience is one of the most prominent aspects in studies on tourist destinations (Harrington and Ottenbacher, 2010), which makes local food an important tourist resource (Björk and Kauppinen-Räisänen, 2016). For Contreras and Gracia (2011), the kitchen is the set of representations, beliefs, heritage, knowledge and practices and / or learning that are associated with food and shared by individuals of a culture or social group. In fact, food is increasingly recognized as a vital element of the cultural tourism market, and it has become a relevant factor, especially for rural places (Hall and Mitchell, 2001; Hjalager and Richards, 2002; Lee and Arcodia, 2011). Furthermore, events favor differentiation among destinations, and it shape the destination's image and brand (Getz, 2000; Hall et al., 2004; Cohen and Avieli, 2004; Allen et al., 2008; Hall and Sharples, 2008). Thus, the organization of festivals allows 
community exhibitions to larger audiences, including regional, national or international visitors (Kim et al., 2010). In fact, events are a source of entertainment to satisfy the wishes of a community (Popescu and Cobras, 2012). Kim et al. (2010) pointed out that festivals allow the host city to create a desirable image through the exposure of resources and also offer families the opportunity to demonstrate their mutual commitment. Moreover, food-related events present opportunities to promote culinary products and increase the attractiveness of the destination (Getz, 2000). The impact of these small festivals is not only relevant for the tourism sector and the sustainable positioning of the destination, however it is also relevant for the local economy due to the consumption of local gastronomic products (Folgado-Fernández et al., 2019). Therefore, rural communities are using food festivals to promote local products (Çela et al., 2007). In this sense, local food is a marker of openness and balance between fine palate and sustainability (Lin and Bestor, 2020).

Festivals are often classified into four categories of interest: leisure and participation, sociological development, community development, and tourism perspective (Okech, 2011). Among the various types of festivals, food festivals are one of the most popular (Wan and Chan, 2013). In addition, there are three key elements in the design of a gastronomic festival: flavor, place and tradition (Organ et al., 2015). A food festival is always a good opportunity for tourists to enjoy local cuisine and have new experiences, and also a way to promote the destination ( $\mathrm{Wu}$ et al., 2014). Festivals are a good place to reinforce regional / local identity and allow the community to display its products (Hubbard et al., 2012). Research aimed at determining visitors' perceptions of food festivals include studies aimed at identifying the benefits of visiting a food festival (Meretse et al., 2015); visitors' perceptions of local foods (Mgonja et al., 2016); visitor motivations (Park et al., 2008; Chang, 2011); visitor satisfaction (Kim Y.G. et al., 2010; Kim et al., 2011); behavioral intentions (Horng et al., 2013; Wu et al., 2014); and a measurement scale for food in the festival visitor experience (Ding and Hoffer, 2017).

The information on the sociodemographic profile of the visitors of a festival can be essential to determine the set of action s necessary to manage the event (Bonet et al., 2009; Cerezuela, 2005). Regarding the origin variables, the majority of festival goers are national tourists (Kim S.S. et al., 2010). Also, the majority of visitors come from the surrounding municipalities, moti vated by the preservation of traditions and countryside (Stojanović et al., 2020). Additionally, for Kim et al. (2015) there is a high educational level of those attending gastronomic festivals. Previous studies on festivals show that the gender variable has a great influence on the attendance of a festival (Carvache-Franco et al., 2018; Yolal et al., 2009). The activities available at food festivals provide easy entertainment for all demographic groups due to the close association between the daily lives of individuals and food (Hu, 2010; Wan and Chan, 2013).

Moreover, attempts to understand the motivation and satisfaction of festival goers derive mainly from past behavioral studies (Kim Y.G. et al., 2010; Kim S.S. et al., 2010; Lee et al., 2010) in which the primary objectives were to identify the levels of satisfaction of festival attendees, motivational factors, or revisit intentions. The behavioral intentions of visitors play an important role in predicting future benefits at the food festival (Wu et al., 2014). In this regard, for Piramanayagam et al. (2020) tasting local gastronomy in tourist destinations provides a memorable tourist experience, satisfy visitors and promote their intentions of revisiting. The referred elements have a pos itive relationship with the loyalty of destiny. For Tichaawa and Idahosa (2020), satisfaction levels significantly influence returning intentions to festivals. Along the same lines, Folgado-Fernández et al. (2017) revealed that loyalty to gastronomic events is positively correlated with the event's brand and the destination's brand and image. Consequently, the mentioned elements have a positive relationship with fidelity to destiny.

Since the literature is scarce on the relationship between sociodemographic variables, loyalty and satisfaction in gastronomic festivals, the present study raises the following research questions about the demand for attendees to these events:

RQ1: What is the relationship between the level of education and satisfaction?

RQ2: What is the relationship between income and satisfaction?

RQ3: What is the relationship between satisfaction and the probability of visiting the festival again?

\section{The Gastronomic Festival of the Red Crab from Ecuador}

The Municipality of Naranjal, under the auspices of the Guayas Prefecture Ministry and the Ecuadorian Chefs Association, organizes the Gastronomic Festival of the Red Crab. This gastronomic event is held annually on the first Sunday of August. In this destination, thousands of visitors attend the event to taste the cuisine based on red crabs. The project was created in 2014 to promote tourism and local economic development. In 2019, 40,000 visitors attended this cultural event whose folkloric dances represent the production of the land and sea. The festival includes foods based on crab, shrimp, banana and cocoa as well as a live music show, entertainment programs, handicrafts, and exhibition of the crustacean capturing, reproducing and selling processes. Naranjal is located in the Guayas province, and its main economic activities are agriculture, commerce, livestock, fishing and the aquaculture. Within the gastronomic offer based on red crab or guariche (Ucides occidentalis) you can find: Creole crab or Chinese crabs, crab salad, encocado crab, garlic sauce, crab soup, rice with crab, crab casserole and shrimp, stuffed carapace, and crab ceviche. These dishes of the local gastronomy were identified by Carvache-Franco et al. (2020) who argue that typical Ecuadorian cuisine is a mixture of flavors and knowledge that fuse the pre-Hispanic diet with Spanish cuisine.

The Guayas Province Prefecture, and the Tourism Department of Naranjal Municipality train the owners of food and beverage establishments and teach them culinary techniques, good manufacturing practices and development of new products to revalue the local gastronomic culture. There are 2,500 fishermen dedicated to the collection of the red crab. Thus, Naranjal is recognized as the Capital of the Ecuadorian Red Crab. In the festival the inhabitants promote the tourist attractions of this destination such as: The Churute Manglares Ecological Reserve, the Seven Waterfalls located in Cerro de Hayas, the Shuar commune and the Hot Springs (Figure 1).

\section{METHODOLOGY}

The present study had the following objectives: (i) to identify the relationship between the level of training and the income level, as sociodemographic variables, and the level of satisfaction of those attending a Gastronomic Festival. (ii) identify the influence of satisfaction on the probability of revisiting a gastronomic festival. The present empirical research was carried out in situ at the Gastronomic Festival of the Red $\mathrm{Crab}$ in Ecuador. Thus, a questionnaire based on different previous studies on satisfaction of gastronomic festivals was used (Folgado-Fernández et al., 2017; Kim et al., 2011; Kim et al., 2015). The instrument consisted of 12 questions, and it was technically organized into two sections: the first section dealt with the sociodemographic information of the visitors, while the second focused on the satisfaction and loyalty of the gastronomic festival attendees. For the present study, the researchers used closed questions and Likert scale ones, which were designed to obtain sufficiently reliable results. The data collection was carried out on Sunday, August 5, 2018, during the Gastronomic Festival of the Red Crab in Naranjal, Ecuador. The survey was completed by national and foreign visitors over 18 years of age, who were the population under study. The information gathering was carried out at the sites within the festival. Attendees were asked to fill out the questionnaires independently after they had tasted the local cuisine. For this purpose, the pollsters were ready to answer any question. The pollsters were students of the Gastronomy Degree of the University of Guayaquil (Ecuador), who were trained by the authors of this article to obtain the sample in the field work. To analyze the effectiveness of the questionnaire, a pilot test was carried out during one day, reaching 10 surveys to validate the tool. 


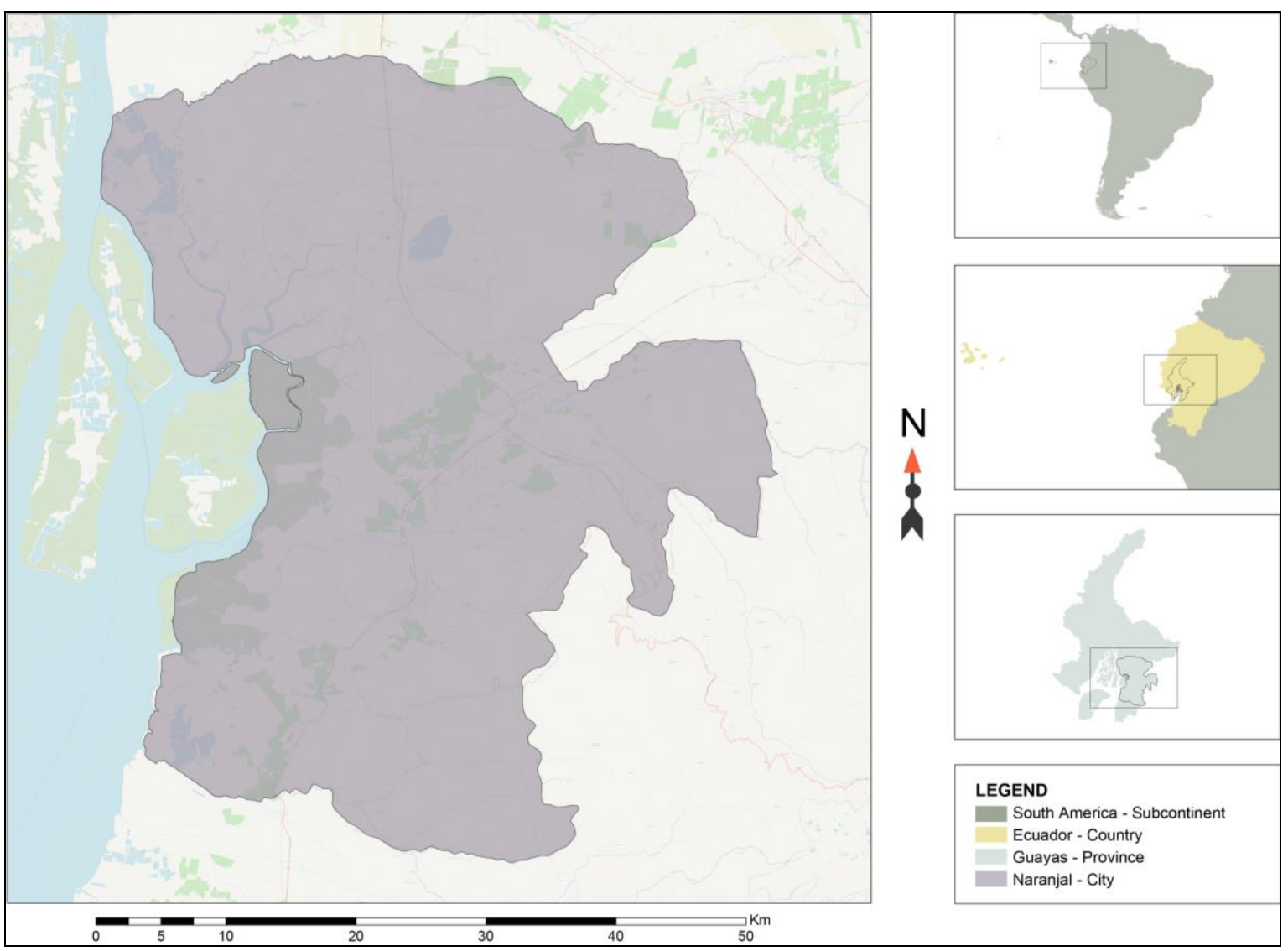

Figure 1. Geographical location of Naranjal, Ecuador

The convenience method was used. Thus, for which 240 questionnaires were applied to, obtain a sample size of 200 valid surveys. For this study, the researchers used the finite population equation considering the 35,000 Festival attendees in 2018. The calculations included a margin of error of $+/-6.9 \%$, a confidence level of $95 \%$ and a variance $50 \%$, (Table 1). To analyze the relationships between the variables, Pearson's Chi square coefficient and Spearman's Correlation coefficient were used. These calculations allowed finding significant correlations between sociodemographic variables and satisfaction, as well as between satisfaction and the probability of returning to the festival. In this research, the data collected were analyzed and tabulated using the SPSS Version 22 program. Also, statistical tools such as Pearson's Chi square were used to obtain valid results.

Table 1. Research methodology

\begin{tabular}{|l|l|}
\hline Population & National and foreign visitors \\
\hline Geographic area & Naranjal city (Guayas, Ecuador) \\
\hline Period & August de 2018 \\
\hline Process & Convenience sampling \\
\hline Confidence level & $95 \%$ \\
\hline Error range & $+/-6.9 \%$ \\
\hline Valid questionnaires & 200 \\
\hline
\end{tabular}

\section{RESULTS}

\section{Sociodemographic aspects and characteristics of the trip}

The results of the sociodemographic variables such as origin, sex, age, level of education, professional activity and income are found in Table 2. Two percent of the respondents were foreigners and $98 \%$ were nationals. Hence, most of the attendees were national tourists (Kim S.S. et al., 2010; Stojanović et al., 2020). Regarding gender, 43.5\% were men and 57.5\% women. In the total sample, 38.51\% were between 20 and 29 years old and 19\% were in the 40-49 age range. Sixty four percent of the respondents had undergraduate studies, $26 \%$ had secondary education and $7.5 \%$ had postgraduate education. Regarding the attendees' occupation, the respondents were mainly students (28.5\%), private employees (25\%) and public employees (10\%). Concerning family income, most of the surveyed people, that is, $39.5 \%$ had an income level of 500 to 1,000 dollars, 36.5\% earned less than 500 dollars, and $14.5 \%$ from $\$ 1001$ to $\$ 1,500$. Regarding the characteristics of the visit, $76.5 \%$ of the visitors attended the festival for the first time and $14 \%$ for the second time. In addition, $54 \%$ of the tourists attended with their family and $32.5 \%$ with friends. On the subject of expenditure, $30.5 \%$ spent less than $\$ 20$ and $25.5 \%$ from $\$ 20$ to $\$ 30$.

\section{General satisfaction and loyalty level}

Respondents rated the level of satisfaction and loyalty of the food festival using a Likert scale of 5 points (1 meant a little and 5 a lot). According to Table 3, the general satisfaction obtained an average of 4.30, which is a high level of satisfaction. The question: Are you to visit this event again obtained an average of 4.29 , which indicates a high loyalty of the attendees.

The level of education and general satisfaction

To analyze the significant relationship between the level of education and satisfaction with the gastronomic festival, the researchers used the Pearson's Chi-square coefficient (Table 4). 
Table 2. Sociodemographic variables and aspects of the visit.

\begin{tabular}{|c|c|c|c|}
\hline Category & Demographic & $\mathrm{N}=\mathbf{2 0 0}$ & $\%$ \\
\hline \multirow[t]{2}{*}{ Nationality } & National & 196 & 98.0 \\
\hline & Foreign & 4 & 2.0 \\
\hline \multirow[t]{2}{*}{ Gender } & Male & 85 & 42.5 \\
\hline & Female & 115 & 57.5 \\
\hline \multirow[t]{6}{*}{ Age } & $<20$ years old & 12 & 6.0 \\
\hline & $20-29$ years old & 77 & 38.5 \\
\hline & $30-39$ years old & 36 & 18.0 \\
\hline & $40-49$ years old & 38 & 19.0 \\
\hline & $50-59$ years old & 24 & 12.0 \\
\hline & $>59$ years old & 13 & 6.5 \\
\hline \multirow[t]{4}{*}{ Level of education } & Primary & 5 & 2.5 \\
\hline & Secondary & 52 & 26.0 \\
\hline & Undergraduate & 128 & 64.0 \\
\hline & Postgraduate/ Master/ Ph.D. & 15 & 7.5 \\
\hline \multirow[t]{10}{*}{ Occupation } & Student & 57 & 28.5 \\
\hline & Researcher/ scientist & 3 & 1.5 \\
\hline & Businessman & 16 & 8.0 \\
\hline & Private Employee & 50 & 25.0 \\
\hline & Public Employee & 32 & 16.0 \\
\hline & Housework & 7 & 3.5 \\
\hline & Unemployed & 1 & 0.5 \\
\hline & Retired & 7 & 3.5 \\
\hline & Informal worker & 2 & 1.0 \\
\hline & Others & 25 & 12.5 \\
\hline \multirow{7}{*}{ Monthly income } & $<500 \$$ & 73 & 36.5 \\
\hline & $501-1000 \$$ & 79 & 39.5 \\
\hline & $1001-1500 \$$ & 29 & 14.5 \\
\hline & $1501-2000 \$$ & 5 & 2.5 \\
\hline & $2001-2500 \$$ & 8 & 4.0 \\
\hline & $2501-3000 \$$ & 3 & 1.5 \\
\hline & $>3000 \$$ & 3 & 1.5 \\
\hline \multirow[t]{4}{*}{ Frequency of visit } & First time & 153 & 76.5 \\
\hline & Twice time & 28 & 14.0 \\
\hline & Three times & 10 & 5.0 \\
\hline & More than three times & 9 & 4.5 \\
\hline \multirow[t]{5}{*}{ Companion } & Alone & 12 & 6.0 \\
\hline & family & 108 & 54.0 \\
\hline & friends & 65 & 32.5 \\
\hline & the couple & 11 & 5.5 \\
\hline & Others & 4 & 2.0 \\
\hline \multirow[t]{6}{*}{ Average daily food expenditure } & Under $\$ 20$ & 61 & 30.5 \\
\hline & $\$ 20.1-\$ 30$ & 51 & 25.5 \\
\hline & $\$ 30.1-\$ 40$ & 26 & 13.0 \\
\hline & $\$ 40.1-\$ 50$ & 18 & 9.0 \\
\hline & $\$ 50.1-\$ 60$ & 22 & 11.0 \\
\hline & More than $\$ 60$ & 22 & 11.0 \\
\hline
\end{tabular}

Table 3. General satisfaction and loyalty

\begin{tabular}{|c|c|c|c|c|}
\hline Variables & $\mathbf{N}$ & Minimum & Maximum & Mean \\
\hline What is the general satisfaction level & 200 & 1 & 5 & 4.30 \\
\hline I think I made the right decision & 200 & 1 & 5 & 4.47 \\
\hline Attending this event was the correct choice & 200 & 1 & 5 & 4.41 \\
\hline Are you likely to visit this event again & 200 & 1 & 5 & 4.29 \\
\hline If I wished to attend a food event next year, I would select this one. & 200 & 1 & 5 & 4.31 \\
\hline
\end{tabular}

Table 4. Relationship between the level of education and general satisfaction

\begin{tabular}{|c|c|c|c|c|c|c|c|c|}
\hline \multicolumn{2}{|c|}{ Variables } & $\begin{array}{c}\text { Primary } \\
(\%)\end{array}$ & Secondary (\%) & $\begin{array}{c}\text { Undergraduat } \\
\text { e (\%) }\end{array}$ & $\begin{array}{c}\text { Postgraduate/ } \\
\text { Master/Ph.D. (\%) }\end{array}$ & $\begin{array}{l}\text { Total } \\
(\%)\end{array}$ & $\chi^{2}$ & Sig. \\
\hline \multirow{4}{*}{$\begin{array}{c}\text { General } \\
\text { satisfaction }\end{array}$} & 1 & & & 2 & 7 & 2 & \multirow[t]{5}{*}{17,466} & \multirow[t]{5}{*}{0.04} \\
\hline & 3 & & 8 & 9 & 20 & 9 & & \\
\hline & 4 & 100 & 35 & 48 & 20 & 44 & & \\
\hline & 5 & & 58 & 41 & 53 & 45 & & \\
\hline \multicolumn{2}{|l|}{ Total } & 100 & 100 & 100 & 100 & 100 & & \\
\hline
\end{tabular}

According to Table 4, there is a significant correlation $(\mathrm{p}<0.05)$ between the level of training and satisfaction with the festival. Therefore, the level of satisfaction of the attendees is influenced by their level of education. In this regard, attendees with a postgraduate degree revealed a high level of satisfaction with the festival. Thus, results that respond RQ1: What is the relationship between the level of training and satisfaction? Showed that the higher the level of education, the higher the level of satisfaction in gastronomic festivals.

\section{Income level and general satisfaction}

To analyze the significant relationship between income level and satisfaction with the gastronomic festival, Pearson's Chi-square coefficient has been used (Table 5). 
Table 5. Relationship between income level and general satisfaction

\begin{tabular}{|c|c|c|c|c|c|c|c|c|c|c|c|}
\hline \multicolumn{2}{|l|}{ Variables } & $\begin{array}{c}<\mathbf{5 0 0} \\
(\%)\end{array}$ & $\begin{array}{c}501-1000 \\
(\%)\end{array}$ & $\begin{array}{c}1001-1500 \\
(\%)\end{array}$ & $\begin{array}{c}\text { 1501- 2000 } \\
(\%)\end{array}$ & $\begin{array}{c}2001-2500 \\
(\%)\end{array}$ & \begin{tabular}{|c|}
$\begin{array}{c}2501-3000 \\
(\%)\end{array}$ \\
\end{tabular} & $\begin{array}{c}>3000 \\
(\%)\end{array}$ & $\begin{array}{c}\text { Total } \\
(\%)\end{array}$ & $\chi^{2}$ & Sig. \\
\hline \multirow{3}{*}{$\begin{array}{c}\text { General } \\
\text { satisfaction }\end{array}$} & 1 & 2.7 & & & 20 & 12.5 & & & 2 & \multirow[t]{4}{*}{28,907} & \multirow[t]{4}{*}{0.049} \\
\hline & 3 & 8.2 & 10 & 6.9 & & 12.5 & 33.3 & & 9 & & \\
\hline & 5 & 37 & 57 & 44.8 & 20 & 25 & & 66.7 & 45 & & \\
\hline \multicolumn{2}{|l|}{ Total } & 100 & 100 & 100 & 100 & 100 & 100 & 100 & 100 & & \\
\hline
\end{tabular}

According to Table 5, there is a significant correlation $(\mathrm{p}<0.05)$ between the income level and the satisfaction of the attendees. Therefore, the level of satisfaction of the attendees is influenced by their income level. Accordingly, attendees with high income levels have a high level of satisfaction with the festival. These findings answer the second research question RQ2: What is the relationship between income and the level of satisfaction? Thus, the higher the income level the higher level of satisfaction in gastronomic festivals.

\section{General satisfaction and likelihood of revisiting the food festival}

To find the relationship between the probability of revisiting the event and satisfaction, a Spearman correlation was performed. According to Table 6 , there is a significant correlation $(\mathrm{p}<0.05)$ between satisfaction and the probability of revisiting the gastronomic festival. This result shows that the probability of returning to the festival is influenced by the satisfaction of the attendees. Therefore, as the satisfaction level of attendees increases, the chances of revisiting the festival increase. When analyzing the most satisfied group of attendees, 84.4\% had a high probability of revisiting the festival. In summary, these results answer the third research question. RQ3: What is the relationship between satisfaction and the probability of visiting the festival again? Therefore, the results revealed that the greater the satisfaction, the greater the chances of returning to the gastronomic festival.

Table 6. Satisfaction and probability of revisiting the festival (Spearman correlation)

\begin{tabular}{|c|c|c|c|c|c|c|c|c|}
\hline & \multicolumn{4}{|c|}{ Satisfaction level } & \multirow{2}{*}{ Total } & \multirow{2}{*}{ Correlation } & \multirow{2}{*}{ Sig. } \\
\hline & & 1 & 3 & 4 & 5 & & & \\
\hline \multirow{5}{*}{$\begin{array}{l}\text { Probability } \\
\text { of revisiting }\end{array}$} & 1 & $100.0 \%$ & $16.7 \%$ & $2.3 \%$ & & $4.5 \%$ & \multirow[t]{6}{*}{0.58} & \multirow{6}{*}{0.000} \\
\hline & 2 & & $27.8 \%$ & $4.5 \%$ & & $4.5 \%$ & & \\
\hline & 3 & & $16.7 \%$ & $9.1 \%$ & $1.1 \%$ & $6.0 \%$ & & \\
\hline & 4 & & $22.2 \%$ & $44.3 \%$ & $14.4 \%$ & $28.0 \%$ & & \\
\hline & 5 & & $16.7 \%$ & $39.8 \%$ & $84.4 \%$ & $57.0 \%$ & & \\
\hline \multicolumn{2}{|l|}{ Total } & $100.0 \%$ & $100.0 \%$ & $100.0 \%$ & $100.0 \%$ & $100.0 \%$ & & \\
\hline
\end{tabular}

\section{CONCLUSIONS AND DISCUSSION}

Gastronomic festivals promote the culture of a destination and its culinary resources to enhance the tourist destination. The present study carried out at the Gastronomic Festival of the Red Crab in the city of Naranjal in Ecuador objectives were namely, to identify the relationship between the level of education and the income of the visitors, as sociodemographic variables, and the level of satisfaction of attendees of a gastronomic festival. In addition, the researchers aimed at identifying the influence of satisfaction on the probability of visiting a gastronomic festival again. Therefore, the researchers conclude that domestic tourists outnumber foreign tourists. Moreover, the level of satisfaction of the attendees is influenced by their income and level of education. In addition, the probability of revisiting the event is influenced by the level of satisfaction of the attendees. As theoretical implications, the authors found that most of the attendees are national tourists (Kim et al., 2010; Stojanović et al., 2020). Among the relationships of the variables we found that the higher the level of training of the attendees, the greater their satisfaction with the festival. These results are similar to Kim et al. (2015). Likewise, the higher the income of the attendees, the greater the satisfaction of the attendees. In addition, attendees with high levels of satisfaction have a high probability of revisiting the event. These results coincide with (Folgado-Fernández et al., 2017; Piramanayagam et al., 2020; Tichaawa and Idahosa, 2020). The contribution to the academic literature is the significant relationship between the level of education and income sociodemographic variables, and the satisfaction of gastronomic festivals. The findings also show the influence of satisfaction on the probability of returning as part of tourist loyalty to gastronomic festivals.

Consequently, the practical implication in the case of Naranjal is a recommendation to improve the satisfaction levels of the visitors at the restaurants where local food dishes are offered during the Gastronomic Festival of the Red Crab. Hence, the quality of the dishes, furniture, food handling and customer service in restaurants are essential details to achieve the goal. In addition, recreati onal activities should be implemented for visitors to boost satisfaction. Meticulous training of the destination managers is recommended. Mor eover, biosecurity measures should be adopted for the coming festivals.

Finally, the main limitation of the present study was the temporality of the sample because the demand can vary. Future research should focus on measuring the satisfaction attributes of food venues in the city of Naranjal during the Gastronomic Festival of the Red Crab.

\section{REFERENCES}

Allen, J., O’Toole, W., McDonnell, I., \& Harris, R. (2008). Organização e gestão de eventos. [Organization and management of events] (3th ed.). Rio de Janeiro, RJ, Campus.

Björk, P. \& Kauppinen-Räisänen, H. (2016). Local food: a source for destination attraction. International Journal of Contemporary Hospitality Management, 28 (1), 177-194. https://doi.org/10.1108/IJCHM-05-2014-0214

Bonet, L., Castaner, X., \& Font, J. (2009). Gestion de proyectos culturales: Analisis de caso [Management of cultural projects: Case analysis]. Espana: Ariel Practicum.

Carvache-Franco, M., Carvache-Franco, O., Carvache-Franco, W., Orden-Mejía, M., Zamora-Flores, F., \& Macas-López, C. (2020). Segmentation by Motivation in Typical Cuisine Restaurants: Empirical Evidence from Guayaquil, Ecuador. Journal of Culinary Science \& Technology, $18(4), 270-287$. https://doi.org/10.1080/15428052.2019.1582446

Carvache-Franco, M., Carvache-Franco, W., Borja Morán, J.L., \& Contreras Moscol, D. (2018, May). Tourist demand characterization. Andean cultural festival Inti Raymi (Ecuador). Journal of Convention \& Event Tourism, 19(3), 248-267. https://doi.org/10.1080/15470148.2018.1459213

Çela, A., Knowles-Lankford, J., \& Lankford, S. (2007). Local food festivals in Northeast Iowa communities: A visitor and economic impact study. Managing Leisure, 12(2-3), 171-186. https://doi.org/10.1080/13606710701339470

Cerezuela, D.R. (2005). Diseno y evaluci on de proyectos culturales [Design and evaluation of cultural projects]. Espana: Editora Ariel S.A.

Chang, W. (2011). A taste of tourism: Visitors' motivations to attend a food festival. Event Management, 15(2), 151-161. https://doi.org/10.3727/ $152599511 X 13082349958190$ 
Cohen, E., \& Avieli, N. (2004). Food in tourism: Attraction and impediment. Annals of Tourism Research, 31(4), 755-778. https://doi.org/10.1016/j.annals.2004.02.003 Contreras, J., \& Gracia. M. (2011). Alimentação, sociedade e cultura [Food, society and culture]. Rio de Janeiro, RJ: Fiocruz.

Ding, D., \& Hoffer, M.L. (2017). A measurement scale for food festival visitor experience. International Journal of Tourism Sciences, 17(3), 180-197. https://doi.org/10.1080/15980634.2017.1349069

Dwyer, L., Forsyth, P., \& Spurr, R. (2005). Estimating the impacts of special events on an economy. Journal of Travel Research, 43(4), 351-359. https://doi.org/10.1177/0047287505274648

Folgado-Fernández, J.A., Di-Clemente, E., \& Hernández-Mogollón, J.M. (2019). Food Festivals and the Development of Sustainable Destinations. The Case of the Cheese Fair in Trujillo (Spain). Sustainability, 11(10), 2922. https://doi.org/10.3390/su11102922

Folgado-Fernández, J.A., Hernández-Mogollón, J.M., \& Duarte, P. (2017). Destination image and loyalty development: the impact of tourists' food experiences at gastronomic events. Scandinavian Journal of Hospitality and Tourism, 17(1), 92-110. https://doi.org/10.1080/15022250.2016.1221181

Getz, D. (2000). Explore wine tourism: Management, development \& destinations. New York, NY: Cognizant Communication Corporation.

Getz, D. (2008). Event tourism: Definition, evolution, and research. Tourism Management, 29(3), 403-428. https://doi.org/10.1016/j.tourman.2007.07.017

Goldblatt, J. (2011). Special events: A new generation and the next frontier. Hoboken, NJ: John Wiley \& Sons.

Hall, C.M., \& Mitchell, R. (2001). Wine and food tourism. In N. Douglas \& R. Derret (Eds.), Special interest tourism: Context and cases (pp. 307-329). Brisbane: John Wiley \& Sons.

Hall, C.M., \& Sharples, L. (2008). Food events and the local food system: Marketing, management and planning issues: C. Michael Hall and Liz Sharples. In Food and wine festivals and events around the world (pp. 40-63). Routledge.

Hall, C.M., Sharples, L., Mitchell, R., Macionis, N., \& Cambourne, B. (Eds.). (2004). Food tourism around the world. Routledge.

Harrington, R.J., \& Ottenbacher, M. C. (2010). Culinary tourism-A case study of the gastronomic capital. Journal of Culinary Science \& Technology, 8(1), 14-32. https://doi.org/10.1080/15428052.2010.490765

Hjalager, A., \& Richards, G. (2002). Tourism and gastronomy. London: Routledge.

Horng, J.S., Su, C.S., \& So, S.I.A. (2013). Segmenting food festival visitors: Applying the Theory of Planned Behavior and lifestyle. Journal of Convention \& Event Tourism, 14(3), 193-216. https://doi.org/10.1080/15470148.2013.814038

Hu, Y. (2010). An exploration of the relationships between festival expenditures, moti- vations and food involvement among food festival visitors Unpublished thesis. University of Waterloo, Waterloo, Canada.

Huang, J.Z., Li, M., \& Cai, L.A. (2010). A model of community-based festival image. International Journal of Hospitality Management, 29(2), 254-260. https://doi.org/10.1016/j.ijhm.2009.10.010

Hubbard, K.W., Mandabach, K.H., McDowall, S., \& VanLeeuwen, D.M. (2012). Perceptions of quality, satisfaction, loyalty, and approximate spending at an American wine festival. Journal of Culinary Science \& Technology, 10(4), 337-351. https://doi.org/10.1080/15428052.2012.735962

Kim, S.S., Choi, S., Agrusa, J., Wang, K.C., \& Kim, Y. (2010). The role of family decision makers in festival tourism. International Journal of Hospitality Management, 29(2), 308-318. http://dx.doi.org/10.1016/j.ijhm.2009.10.004

Kim, Y.G., Suh, B.W., \& Eves, A. (2010). The relationships between food-related personality traits, satisfaction, and loyalty among visitors attending food events and festivals. International Journal of Hospitality Management, 29(2), 216-226. https://doi.org/10.1016/j.ijhm.2009.10.015

Kim, Y.H., Duncan, J., \& Chung, B.W. (2015). Involvement, satisfaction, perceived value, and revisit intention: A case study of a food festival. Journal of Culinary Science \& Technology, 13(2), 133-158. https://doi.org/10.1080/15428052.2014.952482

Kim, Y.H., Kim, M., Goh, B.K., \& Antun, J. (2011). The role of money: The impact on food tourists' satisfaction and intention to revisit food events. Journal of Culinary Science \& Technology, 9(2), 85-98. https://doi.org/10.1080/15428052.2011.580708

Kim, Y.H., Kim, M., Ruetzler, T., \& Taylor, J. (2010). An examination of festival attendees' behavior using SEM. International Journal of Event and Festival Management, 1(1), 86-95. https://doi.org/10.1108/17852951011029324

Lee, C., Lee, J., \& Yoon, Y. (2010). Measuring festival quality and value affecting visitors' satisfaction and loyalty using a structural approach. International Journal of Hospitality Management, 29(2), 335-342. https://doi.org/10.1016/j.ijhm.2009.10.002

Lee, I., \& Arcodia, C. (2011). The role of regional food festivals for destination branding. International Journal of Tourism Research, 13(4), 355-367. https://doi.org/10.1002/jtr.852

Lin, Y.C.J., \& Bestor, T.C. (2020). Embedding food in place and rural development: Insights from the Bluefin Tuna Cultural Festival in Donggang, Taiwan. Journal of Rural Studies, 79, 373-381. https://doi.org/10.1016/j.jrurstud.2020.08.030

Meneguel, C.R.D.A., Mundet i Cerdan, L., \& Vidal Casellas, M. D. (2019). From commercial to cultural: The role of the festival "Firatast una fira boníssima" in the promotion and appreciation of Catalan cuisine. Journal of Convention \& Event Tourism, 20 (2),108-128. https://doi.org/10.1080/15470148.2019.1576564

Meretse, A.R., Mykletun, R., \& Einarsen, K. (2015). Participants' benefits from visiting a food festival - the case of the Stavanger food festival (Gladmatfestivalen). Scandinavian Journal of Hospitality and Tourism, 16(2), 208-224. https://doi.org/10.1080/15022250.2015.1108865

Mgonja, J.T., Backman, K.F., Backman, S.J., Moore, D.D., \& Hallo, J.C. (2016). Factors Moderating and Mediating Visitors' Perceptions About Local Foods in Tanzania. Journal of Gastronomy and Tourism, 2(2), 87-106. https://doi.org/10.3727/216929716X14720551277808

Okech, R.N. (2011). Promoting sustainable festival events tourism: A case study of Lamu Kenya. Worldwide Hospitality and Tourism Themes, 3(3), 193-202. https://doi.org/10.1108/17554211111142158

Organ, K., Koening-Lewis, N., Palmer, A., \& Probert, J. (2015). Festivals as agents for behaviour change: A study of food festival engagement and subsequent food choices. Tourism Management, 48, 84-99. https://doi.org/10.1016/j.tourman.2014.10.021

Park, K., Reisinger, Y., \& Kang, H. (2008). Visitors' motivation for attending the South Beach wine and food festival, Miami Beach, Florida. Journal of Travel \& Tourism Marketing, 25(2), 161-181. https://doi.org/10.1080/10548400802402883

Piramanayagam, S., Sud, S., \& Seal, P.P. 2020. Relationship between tourists' local food experiencescape, satisfaction and behavioural intention. Anatolia, $1-$ 15. https://doi.org/10.1080/13032917.2020.1747232

Popescu, R., \& Cobras, R. (2012). The role of festivals and cultural events in the strategic development of cities. Recommendations for urban areas in Romania. Informatica Economica, 16 (4), 19-29. http://www.revistaie.ase.ro/content/64/02\%20-\%20Popescu,\%20Corbos.pdf

Privitera, D., Nedelcu, A., \& Nicula, V. (2018). Gastronomic and food tourism as an economic local resource: Case studies from Romania and Italy. GeoJournal of Tourism and Geosites, 21(1), 143-157. http://gtg.webhost.uoradea.ro/PDF/GTG-1-2018/276_Nedelcu.pdf

Stojanović, D., Vukić, M., Vukić, K., \& Jovanović, V. (2020). Satisfaction of visitors with food offer at gastronomic festivals in rural areas. Economics of Agriculture, 67(2), 523-536. https://doi.org/10.5937/ekoPolj2002523S

Tichaawa, T.M., \& Idahosa, L.O. (2020). Adapting Herzberg: Predicting Attendees' Motivation, Satisfaction and Intention to Re-Visit a Festival in Cameroon using an Ordered Logit Approach. Tourism Review International. https://doi.org/10.3727/154427220X15845838896323

Wan, Y.K., \& Chan, S.H. (2013). Factors that affect the levels of tourists' satisfaction and loyalty towards food festivals: a case study of Macau. International Journal of Tourism Research, 15(3), 226-240. https://doi.org/10.1002/jtr.1863

Wu, H.C., Wong, J.W.C., \& Cheng, C.C. (2014). An empirical study of behavioral intentions in the food festival: The case of Macau. Asia Pacific Journal of Tourism Research, 19(11), 1278-1305. https://doi.org/10.1080/10941665.2013.844182

Yolal, M., Çetinel, F., \& Uysal, M. (2009). An examination of festival motivation and perceived benefits relationship: Eskișehir International Festival. Journal of Convention \& Event Tourism, 10(4) 276-291. https://doi.org/10.1080/15470140903372020 